\title{
Alegoría: su pertinencia en la predicación y uso en La novena maravilla
}

\author{
Julia SABENA \\ Universidad Nacional de Rosario/Consejo Nacional de Investigaciones Científicas \\ juliasabena@gmail.com
}

\begin{abstract}
RESUMEN
En este artículo se focaliza el recurso de la alegoría como método exegético en la composición de los sermones panegíricos de Juan Espinosa Medrano (Perú, siglo XVII). Se traza el recorrido de la alegoría (y las humanidades en general) en relación -siempre tensacon el cristianismo a lo largo de su historia; y se llega a la Contrarreforma y el uso exacerbado del método en la predicación barroca; particularmente en la oratoria sagrada de Espinosa Medrano, quien abarca elementos diversos y extraídos de distintas fuentes (filosofía natural, mitología clásica, tradición emblemática, relatos bíblicos), a los que hace funcionar como signos de otra verdad mayor, la sagrada. Si bien las preceptivas sagradas impulsaban una predicación más llana y simple, la profusión de alegorías mitológicas, que el autor resemantiza según su interés de guiar la interpretación, pueden explicarse por varias circunstancias, motivos de estudio en este trabajo.
\end{abstract}

Palabras clave: alegoría cristiana, Espinosa Medrano, sermón barroco.

\section{Allegory: his relevancy in the preaching and use in La novena maravilla}

\begin{abstract}
This article focuses on the usage of allegory as an exegetical method in the composition of panegyric sermons by Juan Espinosa Medrano (Peru, 17th Century). It traces the path of allegory (and of humanities in general), which has always been in tense relationship with Christianity throughout its history, and arrives at its exacerbated usage as a method in the Baroque preaching during the Counter Reformation. To enlighten this last moment, it is particularly important the sacred oratory by Espinosa Medrano, who includes elements drawn from various different sources (natural philosophy, classical mythology, emblematic tradition, biblical) that operate as signs of another larger truth, the sacred. While the mandatory sacred preaching drove to plain and simpler forms, the profusion of mythological allegories, which the author resemantizes following his interest of guiding the interpretation, can be explained by several circumstances that will be analyzed in this article.
\end{abstract}

Key words: christian allegory, Espinosa Medrano, baroque sermon.

SUMARIO: 1. La supervivencia del archivo antiguo. 2. Astros. 3. Tradición moral. 4. Encuentro con el cristianismo. 5. Ovidios moralizados. 6. En el Perú, s XVII: alegorías barrocas en La novena maravilla. 7. Alegorías mitológicas. 
Dispuse aplicar a tus dolencias este suave remedio, almivarando con arte tus provechos, y haziēdo que la eloquencia dulce en vozes numerosas te sirva halagos eficaces, para que assientes amistades con los preceptos divinos, con quienes sustentas disgustos de por vida.

(Valverde, "Prólogo" a Santuario de nuestra Señora de Copacabana en Perú)

Luchava (dizen) Hercules con Anteo; ficcion de la Antigüedad, apadrinóla San Ambrosio Doctor de la Iglesia: no me censureis de menos grave, si me valgo de la humana erudición, que si no las autoriza Doctor Clasico, o Santo Padre, nunca me empeño yo en profanidades.

(Espinosa Medrano, La novena maravilla)

La erudición de humanidades sirve para introducir en los sermones elementos decorativos, pintorescos y conmovedores, que sutilicen y adornen la oración. Según la preceptiva de Gracián, su presencia es además una muestra también del ingenio del predicador, por la ajustada colocación de esos elementos, su pertinencia y la relación entre términos al parecer inconexos. La abundancia de citas de autoridad, exhibición desmesurada y muchas veces no de primera mano de erudición, imitatio de clásicos y reelaboración de tópicos, motivos y temas tradicionales, es decir, las "variantes del discurso humanista" (Colombí Monguió "Erudición humanista y saber omnicomprensivo e identidad colonial" 75) que garantizaba la identidad cultural de los letrados como miembros de la respublica de los studia humanitatis (75), funcionaban igualmente para un auditorio que se consideraba elevado en la medida en que se les predicaba 'a lo culto'. Incluso el sector del auditorio que no poseía una biblioteca particular o el público analfabeto estaba también familiarizado con este tipo de erudición: tenemos datos sobre las obras de teatro representadas (y no sólo las obras de teatro escolar, compuestas y representadas en el interior de los Colegios y Seminarios o Universidades), muchas de Lope de Vega, Calderón, y otros autores dramáticos en cuyos recursos compositivos solían encontrarse algunos de estos motivos culturales humanistas y barrocos como la reelaboración del material clásico y otros materiales temáticos usados también en los sermones. Por esta razón, ese acervo que en gran parte será compartido con su auditorio interesa a los fines de la persuasión. Haremos foco en el recurso de la alegoría, presente de manera insistente en los sermones panegíricos de Juan Espinosa Medrano (Virreinato de Perú, siglo XVII), publicados bajo el título La novena maravilla. Es importante aclarar que nuestro autor usa la alegoría no como método compositivo ${ }^{1}$

${ }^{1}$ Sí lo hace en su obra dramática: Amar su propia muerte es una comedia basada en una historia del Antiguo Testamento cuyo personaje principal, Jael, aparece -en consonancia con la tradición exegética- como prefiguración de la Virgen María y es probable que ése haya sido el motivo de elección de la historia. El robo de Proserpina y sueño de Endimión 
sino como método exegético. Introduce lecturas alegóricas a partir de la naturaleza - de datos eruditos sobre elementos naturales-; o parte a veces de una fábula clásica o mitológica; o de un enigma, o emblema, de una cita, etc.

Estos elementos diversos a partir de los cuales son conformadas las alegorías están cohesionados por el rasgo de que funcionan, en el interior de los sermones, como signo de alguna otra cosa, en estos casos como signos de personajes cristianos, de sacramentos, de comportamientos. Se inscriben, en sentido retórico, en el campo del exemplum. Éste ha gozado de atención desde los primeros tratados de retórica, aun cuando puedan ir diferenciándose las épocas en sus preferencias por uno u otro tipo de ejemplos (ejemplo histórico, parábola, símil, fábula, emblema, etc.), y en su utilización. En el caso del barroco, el ejemplo es uno de los modos predilectos para causar la admiratio, ya que está en estrecha relación con la variada erudición enciclopédica: los exempla pueden provenir de los más diversos saberes. Son, al mismo tiempo, un adorno y gala que hermosea la oración y hace lucir el ingenio del orador; además, muy al gusto del momento, "pone delante de los ojos", evidenciando una idea moral abstracta y convenciendo al entendimiento. Con la variedad y buen gusto mueve la voluntad y por último queda mejor grabado en la memoria un símil, por ejemplo, que una verdad desnuda. Por otro lado y a causa de los diferentes niveles de significación, es un recurso compositivo válido para alcanzar a un auditorio variado. Lo dijo Wardropper a propósito del teatro alegórico de Calderón:

Lo mismo que la poesía, la alegoría se presta a ser interpretada según la capacidad del oyente. Es el gran recurso literario que permite a Timoneda, a Valdivielso y a Calderón dirigirse a un público que abarca desde los grandes de España hasta las fregonas de las posadas. (92)

La legitimidad del método alegórico está dada por su uso en las Sagradas Escrituras. Las polémicas en la historia del cristianismo acerca de la interpretación radicalmente literal o alegórica de la Biblia son abundantes: ya Filón de Alejandría, precedente del alegorismo cristiano, creía pertinente una lectura que fuera más allá de la letra en los pasajes oscuros. Sin embargo, a diferencia de la tradición helénica, este autor $-y$ la serie proyectada: Orígenes, San Clemente de Alejandría, etc.defiende la idea de que, al mismo tiempo que las Escrituras guardan un sentido alegórico, conservan asimismo, aunque inferior, el sentido literal. San Agustín advierte tanto a quienes encuentran alegorías aquí y allá como indica que tomar en sentido literal las locuciones figuradas, es una miserable servidumbre (22), y de

es también una alegoría de la salvación del género humano a partir de, como queda claro en el título, la historia del rapto de Proserpina aunada a la de Endimión. 
hecho dedica un capítulo al "Modo de distinguir las locuciones proprias de las figuradas" (36).

Cabe recordar la importancia que la retórica tuvo para San Agustín y el hecho de que le da entrada permanente y legítima al seno de la Iglesia cristiana. Recupera, así, algunas figuras de palabra y de pensamiento que encuentra en las Sagradas Escrituras y las incorpora al repertorio de herramientas del predicador para una mayor y mejor expansión de la palabra divina. Una de esas herramientas es la alegoría.

No sólo aparece como necesaria para cifrar, es decir ocultar el sentido a quienes no son capaces de comprenderlo sino que además el esfuerzo por develarlo es grato al espíritu (concepto que al barroco más culto le resulta particularmente pertinente, como puede leerse en la Carta en respuesta a la que le escribieron, de Luis de Góngora). Esto tiene muchísima importancia para los auditorios 'acicalados' del barroco hispanoamericano, cuya 'carta de ciudadanía letrada', tan mezquinada por gran parte de la comunidad peninsular, estaba dada por el uso -tanto por parte del emisor como por la del receptor- elitista de la erudición y el entendimiento. En $\mathrm{La}$ novena maravilla los elementos alegóricos son variados: mitológicos, naturales, históricos u otros, y no poseen siempre la misma significación, como veremos.

En muchas ocasiones la alegoría se explicita como extensión de la metáfora

si la leche es symbolo de la doctrina, y de la sabiduria, como dize Pierio; los pechos que la brotan son figura de los Doctores, y Maestros de la Iglesia, que manan torrentes de escientifica leche para alimentar las niñezes de la ignorancia $67 \mathrm{~b}$

De manera similar, consigna en la "Oracion Panegyrica de la Feria tercera de Pentecostes" la metáfora del huevo como el Pan Eucarístico: mientras los accidentes son la blanca cubierta, la yema es la sustancia que, al calor de la paloma (el Espíritu Santo), va a ser carne viva en un polluelo, así como el Pan Eucarístico se transforma en Cristo (23a). En el mismo sermón el Lunarejo trae una alegoría de Jeremías, según la cual la perdiz

viendose infecunda, hurta los huevos de la compañera, y fomentalos en su nido: Solet enim furaxi ova comparis fui. Salen à luz los polluelos, y quando sin empacho sale à repastarlos al Prado; en oyendo ellos la voz, y el sonido de las alas de la perdiz, de que procedieron, desamparan à la ladrona, y vanse por natural instinto à la madre $20 \mathrm{~b}$

es, de esta manera, Luzbel, el "espiritu reprobo" que hurtó las almas a Dios; éstas escucharon, el día de Pentecostés, la voz del Espíritu Santo y "començaron los intelectivos polluelos, las robadas avecillas de la humanidad, à escuchar, y reconocer la voz de su verdadero principio" (21a). 
Dichos elementos provenientes de diversas fuentes de erudición se incorporan al armado del sermón en una suerte de vacío de significación intrínseca. Se desprenden de un contexto más natural o primigenio para pasar a formar parte del reservorio simbólico al cual acude el predicador (o poeta, o dramaturgo, en otros casos) en pos de algún símil, alegoría, metáfora, que sirva a los fines de su propósito persuasivo. En esa trasposición, quien compone el sermón dota de nuevas significaciones que están más relacionadas en muchos casos al punto de llegada que al de partida. Lo explica claramente Eduardo Hopkins:

La atribución o imposición de significados adopta la figura de una revelación de significados, como si estos hubieran estado siempre allí esperando que el orador los ponga en exhibición. No se trata sino de una ilusión, pues el orador es quien establece las conexiones de sentido que requiere, por más remotas que fueran. ("La problemática del receptor" 1101).

En todos los casos, para que la comunicación entre el autor y el auditorio se desarrolle exitosamente, hay que tener en cuenta dos factores importantes: en primer lugar, el papel del mundo simbólico compartido. El Medioevo, el Renacimiento y el Barroco comparten, a pesar de la modernidad de los dos últimos en relación al primero, una mentalidad que no me atrevo a caracterizar como simbólica pero sí bien dispuesta a ese tipo de lectura o razonamiento. Dice Mujica Pinilla:

el pensamiento barroco está más cerca del mal llamado pensamiento 'pre-lógico' de los 'pueblos primitivos' que de la filosofía positivista de René Descartes. Es más afín al lenguaje sapiencial y colectivo del mito que a la lógica lineal e individualista del racionalismo crítico. [Los símbolos] participan y forman parte de la naturaleza de las cosas manifestando las realidades que representan. Aquí yace el fundamento del arte figurativo cristiano y la clave hermenéutica para leer el mundo natural como vestigia dei o sacramento divino. ("Humanismo" 221)

El que el Lunarejo utilice símbolos, emblemas, alegorías, mitología, bestiario tiene que ver con esta disposición interpretativa y cultura compartida, de las que rastrearemos algunos antecedentes. No siempre reduce el uso de estos elementos a las significaciones ya fijadas por la tradición, sino que en buena parte los resemantiza según sea su interés, como analizaremos más adelante.

La idea del siguiente apartado es trazar un recorrido por el derrotero no de la mitología grecolatina, sino del conjunto de interpretaciones sobre la misma, que dará como resultado una parte del repertorio de alegorías ${ }^{2}$ y modos simbólicos que

${ }^{2}$ Hablaremos de alegoría en el sentido que da Angus Fletcher (entre otros) al término, como modo simbólico que "dice una cosa y significa otra" (Alegoría 11). Conviene recordar 
funcionará como archivo cultural humanístico en los sermones panegíricos del Lunarejo.

\section{La supervivencia del archivo antiguo}

Las tradiciones merced a las cuales los dioses, héroes y fábulas grecolatinas 'sobreviven' (la expresión pertenece a Jean Seznec) a la decadencia de los antiguos imperios toman su antecedente de la Antigüedad misma, que como mínimo en sus postrimerías daba a la mitología sentidos diversos para hacerla inteligible. Dice Renan en Estudios de historia religiosa:

el mito sólo adquiere toda su significación en las épocas en que el hombre cree vivir aún en un mundo divino, sin noción claramente distinta de las leyes de la naturaleza: ahora bien, mucho tiempo antes del final del paganismo, esta ingenuidad inicial había desaparecido. (26)

Una de las corrientes hermenéuticas se refiere a los dioses como parte de la historia, en la que su humanidad heroica los habría elevado a esa categoría: se trata del evemerismo, retomado más tarde por Cicerón. Otra interpretación los concibe como símbolos cósmicos, como las fuerzas elementales del universo que aparecen transfiguradas en las relaciones mitológicas y se ubican en el cielo: las estrellas y los planetas son divinidades. Ya en Homero habría alguna mención, pero como resultado de un proceso irregular, aunque evolutivo, al final de la era pagana esa identificación estaría completada. En Catasterismos, de Eratóstenes (284-204), las constelaciones tienen significado mitológico y el zodíaco se explica a través de fábulas; de esta manera el Toro es el que raptó a Europa, por ejemplo. La tercera tradición identificada por Seznec, que tiene mucho que ver con la segunda, piensa a ese conjunto de dioses y relatos como alegorías de ideas e ideales del orden de la moral. Atenderemos a la segunda y la tercera tradición porque son las que interpretan de manera simbólica o alegórica, ven algo más que lo que la fábula dice, encuentran sentidos ocultos y esto es lo que, en nuestro siglo XVII, será un método muy potente y fructífero en la predicación de Espinosa Medrano. El recorrido planteado nos permitirá inferir la hondura y pertinencia del método, que de otro modo puede pensarse sólo como un adorno del discurso.

\section{Astros}

La onomástica planetaria tiene su desarrollo aparte. En la época de Platón los planetas no tenían nombre sino que se los mencionaba según los dioses que a ellos

que el desmembramiento y determinación de límites entre símbolo y alegoría se produce recién en el Romanticismo. 
estaban vinculados. Aunque en la Roma de Cicerón (en su De Natura deorum) existe una nomenclatura aparte para esos elementos cósmicos, termina prevaleciendo la anterior, y abreviada; es decir que ya no era por ejemplo "el astro de Cronos" sino simplemente Saturnus. El éxito de la astrología se demuestra en que Augusto adopta la semana planetaria, y los astros no sólo tienen sus nombres divinos, sino que ostentan las facultades de los dioses, influyendo en los microcosmos.

El cristianismo no se pone de acuerdo enseguida en la actitud que adoptaría ante semejante situación. Si a primera vista ese influjo celeste se aparece como demasiado determinante para el espíritu librearbitrista de la nueva religión, a ésta se le hace imposible mantenerse al margen del auge astrológico. En primer lugar, formaba parte de la cultura. Los mismos primeros Padres están inmersos en ella y rechazar un elemento tan importante y tan estrechamente ligado con las otras ciencias habría puesto en situación de inferioridad al cristianismo. Su inteligencia estriba en la actitud que toma ante este tipo de disyuntivas, que es absorber ese tipo de creencias o conocimiento y 'negociar': así, limitando el poder que los astros tienen sobre el hombre, se disponen a coexistir con su influjo. El valor que tienen no es de coacción sino de signo, mediante el cual la Divinidad anuncia sus propósitos. Por otro lado, no es menos cierto que el cristianismo mismo tiene elementos de esa índole en su interior: en las Sagradas Escrituras hay estrellas importantes, astros que acompañan hechos notables, entre otras cosas.

Durante la Edad Media las teorías de las correspondencias acogen este tipo de saber y lo multiplican en todos los niveles: hay que recordar que el cuerpo, los humores, los signos del zodíaco, los vientos, elementos, temperamentos, colores, etapas, etc., están interrelacionados entre sí, se corresponden parcialmente, y constituyen, entre otras cosas, las bases del arte de curar. Esto persiste en el Renacimiento, que debate el lugar que tiene el hombre en esa cosmovisión en la que todos los elementos están interconectados: si no es tan importante como a su criterio debería ser, tampoco sus pensadores se sustraen de ese universo de ideas. En el "circuito espiritual" del neoplatónico Marsilio Ficino, las diversas jerarquías están relacionadas entre sí "por una influencia divina que emana de Dios, penetra los cielos, desciende a través de los elementos y alcanza su fin en la materia" dice en su Theologia Platonica (apud Panofsky 192). Tal como explica Erwin Panofsky,

Todos los seres humanos, bestias, plantas o minerales, son "influidos" (de aquí esta expresión ahora trivial que originalmente es un término cosmológico) por uno o más de los cuerpos celestes. Es la influencia de Marte la que distingue a un lobo de un león (este último es un animal solar); es el efecto almacenado del Sol y Júpiter el que explica las propiedades medicinales de la menta. Todos los objetos o fenómenos naturales están cargados, en un cierto sentido, de energía celeste. (Nota: Desde este punto de vista la línea divisoria entre la ciencia y la magia es tan imprecisa como la que hay entre el goce de la belleza terrena y la veneración 
de la bondad divina. Para Ficino un uso intencionado de los poderes astrales [...] es esencialmente idéntido al uso de las plantas en medicina, porque estas también deben sus propiedades a los cuerpos celestiales). $(193)^{3}$

El autor de Estudios sobre iconología estudia el desarrollo de estas ideas (con el foco en la noción de amor que emana de ellas), que nacen como 'doctrina esotérica' y devienen en una especie de 'juego social', popularizadas por exitosos libros como los Diálogos de amor de León Hebreo y El cortesano, de Castiglione, entre otros. Seznec, por su parte, encuentra - pensando en la absorción no sólo de parte de la cultura en general, que da resultados como el cuadro Melancolía, de Durero, sino del cristianismo en particular- que el Vaticano, entre otras capillas menores, se llena de imágenes astrológicas. Dejamos para estudiar después, en conjunto con el desarrollo de la tradición moral, lo que la Contrarreforma hizo con estos saberes y qué recepciones y usos tuvieron durante el Barroco.

\section{Tradición moral}

Como decíamos más arriba, esta explicación de los textos que encuentra una moraleja o enseñanza en fábulas antiguas que precisamente no las explicitan se remonta a los antiguos, que buscaron la manera de conciliar la filosofía con el saber popular, encontrando un sentido oculto en las narraciones homéricas -que de otro modo conformaban un muestrario de los vicios de los dioses-.

Ya Platón, dice Guthrie en su Historia de la filosofia, pretende purificar los mitos o relatos homéricos quitando la crueldad de sus dioses en la búsqueda de un buen efecto en la gente (16).

Tenemos además el testimonio de Dionisio de Halicarnaso (s. I a.C.):

no se crea que yo ignoro la utilidad de los mitos griegos. Algunos designan con alegorías las operaciones de la naturaleza; otros ofrecen consuelos en las calamidades humanas; otros sirven para quitar las preocupaciones y varios terrores... Pero los acojo con reserva y prefiero la teología romana á la griega

${ }^{3}$ Desde este marco es que se desprende la comprensión de la naturaleza y el hombre como un complejo de signos (vestigios, analogías, símiles) que desarrolla San Agustín y que permite la lectura del mundo (tópico del liber mundi) como portador de una significación diferente de sí mismo, lo cual también será retomado y utilizado por Espinosa Medrano en sus sermones, buscando gran parte de sus exempla en el libro de la naturaleza. Curtius, en su breve descripción del tópico, inserta una cita de Luis de Granada que ilustra esa actitud alegórica, en el sentido en el que nos estamos refiriendo a ese modo de representación- ante la creación: “¿Qué es todo este mundo visible sino un grande y maravilloso libro que Vos, Señor, escribistes y ofrecistes a los ojos de todas las naciones...? ¿Qué serán luego todas las criaturas deste mundo, tan hermosas y tan acabadas, sino unas como letras quebradas e iluminadas que declaran bien el primor y la sabiduría de su autor...?" (apud Curtius 449). Dentro de esta concepción entra también la lectura del firmamento. 
porque pocos hacen buen uso de tal filosofía; el vulgo toma la parte peor y de aquí nacen el desprecio de los dioses y la disposición á pecar. (Cantú 714)

Virgilio da una versión más moralizada de los dioses que las historias en las que se complace Ovidio. Cicerón, en su De natura deorum, recoge las diferentes interpretaciones de los mitos, y poco después el pseudo Heráclito (siglo I) introduce de esta manera sus Alegorías homéricas:

Se acusa despiadadamente a Homero por su falta de respeto para con la divinidad: todos sus relatos resultarían impíos, a menos de interpretarlos como alegorías. Historias sacrílegas, repletas de una locura blasfema, rezuman furor a lo largo de los dos poemas. Presumir que toda visión filosófica está ausente, que estas obras no esconden ningún sentido alegórico que haga pensar que están exentas de poesía, supondría hacer de Homero un Salmoneo o un Tántalo... Si hay hombres que, faltos de inteligencia, no comprenden el lenguaje alegórico de Homero y no descienden a las profundidades de su sabiduría; que rechazan la verdad sin ser capaces de discernirla; que no entienden tampoco el carácter filosófico que impregna sus relatos, y se aferran a lo que parece tener una conformación legendaria, que estos hombres desaparezcan de nuestra vista. Y nosotros, que hemos sido purificados, tras haber hecho las sagradas abluciones, sigamos las huellas de la augusta verdad bajo las directrices de los dos poemas. (apud Crosas López 30)

Vemos en las citas precedentes cómo hay un "buen uso" del componente mitológico que formaba parte de la cultura de todo hombre letrado, quien se siente impelido a glosar las fábulas y descubrir ese sentido oculto bajo la apariencia de relatos ignominiosos. Esta apariencia sólo puede ser sorteada por algunos, no por el vulgo, que se queda sólo con la corteza.

En este sentido, Angus Fletcher examina el término 'alegoría' etimológicamente: mientras allo quiere decir 'otro' en griego, agoreian significa 'hablar públicamente', con una connotación política. El autor considera que tendría que ver con el hecho de que la censura provoca modos de hablar desviados o irónicos. En última instancia, el modo alegórico es entendido como un proceso de codificación en el que se dice algo para significar otra cosa que está más allá (Fletcher 12). En este sentido, el ejemplo de la personificación de abstracciones, cara a griegos y romanos, es ilustrativo. $\mathrm{O}$, en el caso que estamos viendo de las historias homéricas, se da el proceso inverso, la decodificación, que presupone un significado oculto y propone una lectura diferente de la literal.

Los neoplatónicos utilizan este método ya no sólo con las obras de Homero, sino que el mundo entero contiene para ellos un gran sentido oculto. Se incorporan cultos extranjeros a la mitología grecolatina, de manera desordenada, pero que busca adecuar los viejos (y a veces no tanto) saberes con la nueva corriente de pensamiento y con los nuevos escrúpulos que ésta les presenta. 
Macrobio (s. IV d.C.), autor frecuentemente aludido por el Lunarejo, dice:

Solo se llega á la inteligencia de los misterios por los oscuros caminos de la alegoría. La naturaleza no se manifiesta abiertamente ni aun á los iniciados: solo á los hombres eminentes en sabiduría es dado ser intérpretes de estos secretos: á los demás les basta ser conducidos á la veneracion de las cosas santas por medio de imágenes simbólicas. (Cantú 715)

Tenemos, entonces, que la mitología representa, envuelve y protege a los misterios verdaderos, es su égida.

\section{Encuentro con el cristianismo}

Clemente de Alejandría, cuya 'acomodación' de la fábula de Orfeo a Cristo pone Gracián como ejemplo de la ingeniosa aplicación y uso de la erudición noticiosa (Agudeza y arte de ingenio 349) dice: "Los escritos de Orfeo y Hesiodo tienen dos sentidos, uno literal, otro alegórico. El vulgo toma el primero; los filósofos siempre admiraron el segundo." (Cantú 714) Aparece nuevamente el rasgo que continuará presente y que es muy importante para el periodo humanista, y es que el entender que existe un sentido más allá del literal, y más aún, esclarecerlo, es patrimonio de algunos pocos claros entendimientos; esto los separa del ignorante vulgo que no entiende sino la letra tal cual está expuesta. Así podrá entenderse mejor la labor del predicador como guía de estos sentidos ocultos. Dice el mismo autor, maestro de Orígenes:

Todos los que han tratado de las cosas divinas, Bárbaros ó Griegos, ocultaron de una vez para siempre los principios de las cosas y solo manifestaron la verdad bajo enigmas, símbolos, alegorías y metáforas. Los que instituyeron los misterios que eran filósofos, encubrieron los dogmas con fábulas á fin de que no todos los comprendiesen. El leon, el buey, el caballo, el escarabajo, son símbolos. La explicación de los símbolos ayuda para muchas cosas; por una parte conduce al conocimiento exacto de la teología y por otra presenta al entendimiento la ocasión de ejercer su sagacidad. (Cantú 715)

Clemente de Alejandría había sido educado en lo más excelso de la cultura clásica con agregados de otras culturas, y el modo simbólico con que las lee le permite, entre otras cosas, mantenerlas en los planes de estudio. Plantea que la oscuridad u opacidad de los textos es necesaria para esconder los misterios a quienes no son capaces de comprender; por otro lado, vemos que también le encuentra un sentido positivo al estímulo del entendimiento que eso motiva. Este tipo de interpretación espiritual, del que será Orígenes su mayor representante en Alejandría, permite la conjunción del catolicismo con el vasto campo de erudición propio de esa escuela. No sólo se interpretarán alegóricamente los mitos y las fábulas paganas, sino también el mundo natural, y las Sagradas Escrituras, 
constituyéndose un tipo de alegoría llamado 'figura', que veía en el Antiguo Testamento no sólo la historia del pueblo de Israel sino, y es aquí donde se encuentra su sentido mayor, la prefiguración de Cristo y de los personajes del Nuevo Testamento. En la historia cristiana y en sus hechos, aquellos de la antigua ley -sombra de la futura ley verdadera- encuentran el cumplimiento y la perfección (Auerbach 100 y ss) La diferencia, es necesario aclarar, entre el método figural y el alegórico (restringiendo este uso ahora para la mitología antigua) es que, mientras el primero acepta como verídico el hecho narrado que -además, y sobre todoprefigura la verdad cristiana, el segundo encuentra la verdad disfrazada bajo mentiras y fingimientos.

De modo que estos métodos hermenéuticos cuadraron bien a los misterios del cristianismo, que ha tomado muchos elementos de filosofías anteriores o corrientes contrarias a su fe. Incluso, pese al carácter de verdad revelada e incuestionable que ostenta la doctrina católica, se sirvió casi desde sus comienzos de la retórica, como arte del bien decir que implica un uso no 'transparente' del lenguaje, reconociendo que era necesaria para la adecuada persuasión de los auditorios. En este mismo sentido la Iglesia se vio impelida a acoger en su seno, de una u otra manera y a pesar de las reticencias primeras, el acervo de la cultura clásica. Como indican Reynolds y Wilson en Copistas y filólogos. Las vías de transmisión de las literaturas griega y latina, gran parte del clero intimó a los creyentes a desechar los autores paganos que hasta el momento se estudiaban en los círculos letrados; pero esta actitud, evidentemente, fue parcial, ya que algunos integrantes de la Iglesia católica entendieron que, en relación, había pocos clásicos literarios cristianos que pudiesen reemplazar la literatura pagana de manera aceptable (53). Por otro lado, era un modo inteligente de captar adeptos instruidos si se incluían de alguna manera los libros en cuestión, sobre todo demostrando que los mismos trataban asuntos importantes de la nueva fe, aunque no de manera explícita. La interpretación en clave alegórica tuvo en este sentido un gran éxito, al transformar en inofensivos ciertos pasajes que podían resultar inadecuados a la moral cristiana.

Dentro de la parte más liberal del clero cristiano se encuentran, entre otros, el citado Clemente de Alejandría y San Gregorio Nacianceno, quien criticaba el completo rechazo de algunos cristianos por la literatura pagana, que podía ser de utilidad. Juliano el Apóstata había prohibido la enseñanza de las letras clásicas, y el de Nacianzo dice, en una elocuente defensa de las humanidades paganas en el interior del cristianismo:

De todos los atentados cometidos por este príncipe, éste es el más inicuo y odioso. Quien como yo se honre de profesar á las letras el amor que les tengo, tomará parte en mi indignación. Renunciaría de buen grado en quien las quisiese, la fortuna, el explendor de la posicion social, el poder, la gloria, todos los objetos de la vanidad de los hombres, como sus sueños frívolos; pero la ciencia, las letras, 
jamás! Este es nuestro dominio, el dominio del que nunca se expulsará á los cristianos (apud Rubió y Lluch 50).

La escuela de Orígenes no sólo animaba a la lectura de los clásicos, sino que adoptó la crítica textual para las Sagradas Escrituras, haciendo un cotejo de variantes entre la versión de los Setenta del Antiguo Testamento y el texto hebreo. Aplicando el método alegórico a la exégesis bíblica (en un sentido algo extremo, ya que eliminaba por completo el significado literal), fue quien planteó que el Esposo y la Esposa de El cantar de los cantares eran Cristo y la Iglesia. El espíritu alegórico que animaba la escuela de Alejandría, penetrada de helenismo, se expandió por Occidente.

A finales del siglo IV Servio escribe sus comentarios sobre la obra de Virgilio, escolios que tendrán una amplia proyección en la literatura posterior. En ellos, el gramático atribuye una intención alegorética al autor latino y, en ese sentido, busca en sus poemas las claves para una acabada interpretación más allá de la letra. Fulgencio, un siglo más tarde, se valdrá del mismo punto de partida y tomará a la Eneida como símbolo de la vida humana; además de resumir y explicar medio centenar de fábulas al modo de la Expositio, "el modo característico de la amalgama cristiana del senequismo y el neoplatonismo" (Valero Moreno 118).

Aunque los peligros que entrañaba el método (y su abuso) eran fácilmente perceptibles, los cristianos eruditos no dejaron de aprovechar estos comentarios paganos, donde como mínimo se reducía el alcance de los dioses y la mitología a un papel inocuo, pero en general convertían los mitos paganos en parte de una filosofía de la moral.

Para no inquietar a los cristianos escrupulosos, quienes pretendían dotar de legitimidad a los estudios clásicos en la tradición religiosa se amparaban en alegorías extraídas de la Biblia. San Ambrosio, por su parte, fue quien popularizó la doctrina de San Clemente y Orígenes, transmitiéndosela a su discípulo San Agustín. Éste entiende, después de su conversión, que debía ponerse todo el conocimiento al servicio de la fe. Considera, según Curtius, que

todas las palabras de la Biblia que no se refieren directamente a la fe y a la moral tienen un sentido oculto; continúa así las alegorías que en la tardía Antigüedad se hicieron de Homero y Virgilio, y también las tradicionales alegorías de la Biblia, iniciadas por Orígenes. San Agustín justifica estas alegorías diciendo que el esfuerzo por revelar el sentido oculto de la Biblia es un ejercicio sano y grato para el espíritu. (115)

Esta manera literaria o estética de acercarse a las Sagradas Escrituras será uno de los argumentos más fuertes que sostendrá la actitud alegorizante tanto sobre la mitología como sobre la astrología o la naturaleza misma. "El pueblo hebreo, al salir de Egipto, llevó consigo los jarrones de oro y plata de sus enemigos; el 
cristianismo hará lo mismo" (70) dice San Agustín, programático, dando el paso decisivo hacia la acomodación de las humanidades a la doctrina cristiana. Recordemos la pertinencia de tomar aquello que los gentiles tenían de bueno como de "injustos poseedores' "para hacer de todo ello mejor uso" (256); porque lo que tenían de bueno tampoco era de ellos, sino que la providencia lo había esparcido. Así,

quando un Christiano se separa de todo su corazon de la infeliz sociedad de los infieles, debe quitarlos esos bienes, i riquezas para emplearlas justa i debidamente en la predicacion del Evangelio. Tambien sus adornos i vestidos, esto es, sus instituciones puramente humanas, pero utiles à la sociedad de los hombres, sin la qual no podemos pasar esta vida, es lícito cogerlos i guardarlos, para aprovecharse de ellos invirtiendolos en usos christianos. 258

Esto mismo es lo que han hecho San Cipriano y Lactancio Firmiano (s. III), entre otros, continúa el de Hipona, que desarrolla a lo largo de su obra ingeniosos símiles y alegorías, generalmente a partir de las Escrituras. Lo mismo hará San Gregorio Magno, otro nombre frecuente en los sermones del Lunarejo. Todo este caudal simbólico será retomado y respetado por la Edad Media, que, en palabras de Emile Mâle, poco agregará al corpus, repitiendo incansablemente a los Padres de la Iglesia o directamente al compendio que de ese archivo hizo Isidoro de Sevilla (Mâle 173).

\section{Ovidios moralizados}

En el terreno de la alegoría más puramente moral, aunque no estrictamente pagana, la Edad Media ofrece una tradición aparte. Se trata de los ovidios moralizados. Según Seznec, esta serie tiene su tímido origen en el siglo VIII en palabras de Teodulfo, obispo de Orléans, acerca del autor latino: "Aunque muchas cosas sean frívolas, / muchísimas verdades yacen ocultas bajo un falso velo" (apud Seznec 82), pero en líneas generales sigue la tradición edificante de Fulgencio y de Marciano Capella en su alegoría de las artes liberales.

En el siglo XIV aparece el Reductorium morale, obra enciclopédica del benedictino francés Pierre Berçuire o Petrus Berchorius, quien dedica el libro 15 a Las morales de Ovidio, una lectura altamente edificante de las Metamorfosis. Es evidente que su obra era conocida en el Virreinato de Perú, ya que tanto el Lunarejo en sus sermones como Antonio de la Calancha en su Coronica moralizada del orden de San Agustín en el Perú lo mencionan (como Berçuire) con muchísima frecuencia.

Del ovidio moralizado de Berçuire tenemos una traducción hecha al castellano por-según parece- Alfonso de Zamora, a instancias -también es una conjetura- del Marqués de Santillana (Carr "La transformación de las Transformaciones" pág. 12). Según el autor del artículo, que ha estudiado y hecho una edición crítica de la 
traducción en cuestión ("El lenguaje y el léxico de los Morales de Ovidio"), los cambios efectuados por ésta son del orden de lo lingüístico, pero no producto de una labor de editor humanista, sino bastante literal, aunque tampoco exenta de elegancia. Por este motivo nos fiaremos de que, a grandes rasgos, el texto resultante no difiere del original, y lo citaremos como si de referencias de éste se tratase.

El autor comienza con una justificación del método que ya conocemos: su uso en las Sagradas Escrituras, la necesidad de las fábulas según San Pablo Apóstol ("Algunos de la verdat desvian su oydo \& conviertense alas fablas" f.1). Declara que no tratará del sentido literal, pues ya lo han hecho Fulgencio, Alexandre y Servio; además, "[c]a el natural entendimiento non es del presente proposito, onde non se tracta sy non dela reduccion moral" (f.2).

En el primer capítulo del primer libro, citando sobre todo a Fulgencio y a Marciano Capella, describe a los dioses más importantes del Olimpo según la iconografía vigente, y presenta la moralidad de cada uno. En el segundo capítulo inicia la explanación que se desarrollará en lo que resta, libro por libro, de las Metamorfosis, declarando primero la letra y a continuación las alegorías extraídas.

Poco después Boccaccio escribirá su Genealogía de los dioses (Genealogia deorum), nutrido de la común tradición: Servio, Macrobio, Marciano Capella, Lactancio y San Agustín, entre otros. Entendiendo, como dice en su libro XIV, a la fábula como "modo de hablar con ejemplos o demostraciones bajo una ficción, quitada la corteza de la cual aparece la intención del compositor de la fábula" (823), las clasifica según sean más lejanas o cercanas a la historia, y considera, como el resto de los alegorizadores, que pueden tener más de una interpretación: la literal, la moral, la alegórica.

En el siglo XVI aparece la Mitología (Mythologia) de Natal Conti o Natalis Comes, obra escrita en latín a la que continuamente vuelve Espinosa Medrano, llamándolo Natal Comte. Obra del erudito humanista residente en Venecia, Mitología recupera lo realizado por los mitógrafos que lo antecedieron y agrega a ello su capacidad de lectura de los clásicos griegos. Y, como sucede en general, escatima la mención de las fuentes utilizadas e incluso niega que haya precedentes en la explicación de fábulas antiguas.

Los griegos no sólo trajeron las fábulas, dice Conti, sino sobre todo su modo secreto de filosofar

con la intención de que las cosas dignas de admiración no se revelasen al vulgo para que éste, mal comprendidas aquéllas, se apartara con facilidad a menudo de la religión y de una completa integridad [...] Después como, con el transcurrir del tiempo, quedara al desnudo el contenido y fuese sacado de ellas a la luz todo el recto modo de filosofar, unos pocos examinaron atentamente las fábulas, antigua sede de la filosofía por así decir, y creyeron que éstas habían sido o bien una inútil teología de hombres ignorantes o bien naderías de viejas y vanas ficciones de poetas embusteros. (47) 
Y esa sería la razón, además, de la censura del uso de las fábulas por parte de la ortodoxia cristiana: sólo se debe al desconocimiento del arte de fabular, ignorancia que este libro viene a zanjar, poniendo en evidencia cuanto no fue explicitado por los antiguos, para provecho y placer de los lectores. Es por esto que -se encarga de aclarar y enfatizar- se separa, evidentemente, de los 'ovidios moralizados' ("no ofreceremos ninguna interpretación de hombres cambiados en árboles" 48) y de explicaciones de fábulas de monstruos y prodigios, puesto que busca sólo la elevación y honradez. Se compara al médico -boticario- que convierte lo pernicioso en adecuado gracias a la calidad de la mezcla.

Conti atribuye utilidades varias a los relatos fabulosos y según ellas los clasifica: aquellos que contienen los secretos de la naturaleza y los arcanos, los que ponen de manifiesto verdades, las fábulas que reprimen vicios o exhortan a la virtud: "a partir de ellas aprendemos con singular deleite los preceptos para pasar la vida con rectitud, a los que continuamente volveríamos la espalda sin el atractivo de las fábulas" (49).

Esa función que le otorga Conti a la mitología no será otra en la oratoria sagrada del seiscientos cuya práctica, amén de la tradición preceptiva eclesiástica que venimos siguiendo en la que se aconseja un uso moderado de 'lugares' en general, abunda en el uso de exempla, sobre todo imágenes, símiles, parábolas, que servían a los fines de "predicar a los ojos", tan del gusto de ese siglo (cf. Aragüéz Aldaz, José. "Preceptiva, sermón barroco y contención" 94).

Terrones del Caño declaraba, en relación al uso de fábulas y jeroglíficos o emblemas, que una vez en cincuenta sermones está bien, y sólo si son de autor grave como Pierio Valeriano o Alciato. Las censuras por el uso excesivo se multiplican entre los tratadistas (también en Luis de Granada, Diego Valadés, Estella), pero las poéticas más representativas lo sancionan por las ventajas que comporta. Además, los auditorios estaban habituados al tipo de sermón que sorprende y entretiene.

Asimismo, como mencionamos más arriba, Gracián pondera la introducción de fábulas alegorizadas en su discurso LIX de la Agudeza y arte de ingenio, "De la ingeniosa aplicación y uso de la erudición noticiosa". El jesuita recomienda empezar un sermón con alguna erudición curiosa para ganar la aceptación y como ejemplo da la acomodación que hizo Clemente de Alejandría de la fábula de Orfeo a Cristo Señor nuestro (349), aunque Terrones del Caño advertía muy bien acerca de los peligros ruines de comenzar un sermón con una fábula pagana.

\section{En el Perú, s XVII: alegorías barrocas en La novena maravilla}

O mal aya el padre infame de las mentiras; mal aya la fabulosa Gentilidad, que por remedarnos tan altos Mysterios, profanò con sus patrañas nuestras verdades. 35a 
Como estudia Weisbach en Barroco, arte de la Contrarreforma, la Iglesia vislumbra la posibilidad de interpretar a las figuras religiosas dándoles un sentido heroico, si en su representación se concebían con ciertos rasgos de héroe o Dios de la Antigüedad (81). Ese intelectualismo humanista tan presente en el Renacimiento podía servir, de esa manera, para enaltecer, mediante un uso codificado y simbólico o alegórico, los preceptos del cristianismo, elevados a una categoría universal gracias a esos rasgos reconocidos por todos y desde siempre.

Esto se agudiza en el Barroco, en el que los elementos iconográficos llegan a revestir multitud de valores y significados; se multiplican además los puntos sensuales en los que se apoya fuertemente el objetivo de persuasión, y de esta manera se llega al siglo XVII con un "pacto" entre "la Iglesia, el mundo y el arte" a partir del cual la Iglesia acepta transigir y hacer concesiones a los artistas y al público, y las Iglesias se llenan de pinturas alegóricas e imágenes grecolatinas representando a los santos, y los sermones, correlativamente, se pueblan también de alegorías, símbolos y apelaciones varias al imaginario creado en gran parte por el efluvio pictórico y emblemático. En el barroco, tiempo de íntimas inquietudes, los antiguos héroes convertidos simbólicamente en santos, y los santos cristianos, héroes de la fe católica, se confunden en una fructífera transposición que encuentra resonancia y proyección en las circunstancias espirituales de la época.

De toda la variedad alegórica que mencionamos, la más notoria y frecuente es la que acude al acervo mitológico o mitográfico, por lo tanto será de la que más en profundidad nos ocuparemos. Sin embargo, la interpretación figural ocupa asimismo un lugar importante en los sermones de La novena maravilla, y las alegorías a partir de los astros, o de otros elementos (ya desarrollamos los naturales), que el Lunarejo habitualmente menciona también como 'figura' o, como adelantamos, 'sombra'.

En un momento de la encendida "Oracion Panegyrica à la Concepcion de nuestra Señora”, predicada en la Catedral de Cuzco, Espinosa Medrano introduce una alegoría que en un principio parece ser propia, después de plantear algunas interpretaciones a las que descarta, y la anuncia como original: "Dexadme correr el velo à una alegoria no vulgar" (58a). Propone que el ángel fuerte del Apocalipsis, 10 es el rey de España, y desarrolla la alegoría en sus partes:

El Iris que le corona, no indica la hermosa variedad de sus muchas Coronas, y Señorios? Las colunas con que pisa el Mar, y la tierra, no symbolizan su potencia en dos Mundos, y las Columnas Herculeas, que blasonando el Plus ultra, pisan como piernas el Occeano? El rugido de Leon no pregona, que hablava el Leon de España? Quem adcodum Leo rugit? El rostro de Sol quarto entre los Planetas, no señala à Filipo? Si; que Filipo tambien quiere dezir cara de Luz, rostro de antorcha: $58 \mathrm{a}$ 
Nos dice, después, sin embargo, que es de Vechieto, "Author gravissimo", quien había creado ese concepto. El rey Felipe IV, el ángel en cuestión, había dado un paso definitorio para la afirmación del culto mariano en Europa, por lo tanto será venerado también por nuestro predicador cuzqueño, asumiendo en la propagación de esa alegoría una estrecha vinculación con el presente y la Historia, y la historia de los dogmas cristianos. Es algo que se repite constantemente en la obra concionatoria de Espinosa Medrano, sobre todo en relación con la defensa del inmaculismo, del tomismo ortodoxo, y algunas disputas teológicas, por ejemplo (como será el caso, además, de la pieza dramática creada en torno a la polémica entre las órdenes jesuita y dominica conocida como De Auxiliis, acerca de la posibilidad de libre arbitrio y el papel de la Gracia: El robo de Proserpina y sueño de Endimión). Es un anclaje lógico teniendo en cuenta las características del sermón como comunicación entre el núcleo letrado y un público en gran parte analfabeto.

Los conceptos de 'figura', 'sombra' y símbolo parecen estar usados indistintamente para designar un significado allende el literal. Por otro lado, 'figura' y 'sombra' se usan también para la interpretación figural propiamente dicha que, si encuentra ese sentido más allá de la letra, igualmente considera que los hechos efectivamente sucedieron: la serpiente de bronce que curaba a los murmuradores de Moisés "fue figura de Christo bien nuestro" (54b); el profeta Eliseo, que resucitó al hijo de la sunamita, es, en paradojal contraste, "luziente sombra del Verbo Encarnado" (22a). La metáfora de la sombra, como dijimos, es de frecuentísimo uso, y se basa en la idea de que aquello que narra el Antiguo Testamento no es más que sombra de la luz que traerá Cristo, en quien el Plan Divino se cumplirá. La ley mosaica anticipa la evangélica, luminosa y verdadera. En palabras de Espinosa Medrano:

fue la Religion Mosayca la Noche figural, à cuyas obscuridades de enigmas, y Profeticas tinieblas avia de succeder el clarissimo dia de la Ley de Gracia 15.

La Virgen María es prefigurada por varias mujeres en el Antiguo Testamento: la mujer del Apocalipsis, como ya se describió; Eva (en contraste, ya que es "Maria mejor Eva" 38b); la "mujer fuerte" de Proverbios (103b).

El cielo con sus astros es otra fuente recurrente de material para las alegorías. En el sermón a la Encarnación, por ejemplo, parte en la salutación de un pasaje bíblico de Job, en el que Dios se ufanaba de haber creado las Pléyades -deja de lado a Orión, del mismo fragmento-, para detenerse en lo que "dezian los mentirosos Griegos" (28). Expone la fábula mitológica que da lugar al origen de los astros para luego hacerlo con las Pléyades "a lo divino". Es esta una categoría harto frecuentada en los siglos de oro, sobre todo en la pintura: "lo humano" tenía su correlato "a lo divino" y viceversa. Es, como toda la alegorización que estamos viendo, una manera de aproximar lo religioso a lo humano. Dice Weisbach refiriéndose a la plástica: 
se aproxima lo divino a lo humano con toda clase de ingeniosidades, artificios y recursos naturalistas e ilusionistas para que a las gentes de tipo medio les sea fácil y cómoda la posibilidad de identificación con lo santo. El carácter artístico es esencialmente exotérico. 329

Este punto es primordial para interpretar las alegorías y simbolizaciones en los sermones. Es importante tener en cuenta que en la época existe un uso frecuente de temas astrológicos. La astrología como saber contaminaba todas las esferas de la vida humana; su divulgación era muy frecuente, aunque fuera sólo acerca de influjos generales. Como expusimos más arriba, la Iglesia tiene una relación de 'negociación' con el discurso de los astros: no le es posible prohibir un elemento tan arraigado en la cultura y en los saberes humanísticos, que gozaban del prestigio erudito que la Iglesia reclamaba para sus miembros. Sin embargo, se muestra reticente y adopta la distinción que ya había hecho San Isidoro entre la astrología natural y la astrología supersticiosa, que es la que tiene lugar cuando

los astrólogos tratan de encontrar augurios en las estrellas y descubrir qué es lo que los doce signos del zodíaco disponen para el alma o para los miembros del cuerpo, o cuando se afanan en predecir, por el curso de los astros, cómo va a ser el nacimiento y el carácter del hombre. 447

El Concilio de Trento prohíbe algunos de los libros astrológicos que circulaban. Sin embargo, es evidente por el uso frecuentísimo de la astrología en el barroco que era un saber que gozaba del gusto popular. En la obra del Lunarejo se encuentran alusiones varias a lo que sería la astrología "natural", los efectos de los astros en la tierra, los augurios, entre otras.

Santa Rosa, en el sermón dedicado a ella, nace bajo el influjo del Can del Cielo, de "maravillosos efectos" y por eso creció como flor privilegiada. 268

La "Oracion Panegyrica a la Renovacion de el Santissimo Sacramento" se abre con una salutación curiosa que toma su punto de partida en la cena de Trimalción, de Petronio. En ella se presenta un plato que tiene representados los doce signos del Zodíaco, y esto le sirve al Lunarejo para centrar su atención en los elementos de la bóveda celeste. Haciendo mención al momento de enunciación del sermón, agosto, en que el signo es Virgo, "brilla el Sol por Agosto entre los trigos de una Virgen" (10), lo que prepara perfectamente el paralelo con la Virgen Maria y Cristo, el Sol de Justicia. Y no se despide sin antes dejar constancia de los buenos augurios de los astros: "Todo promete oy felicidades, el Cielo està propicio, el Signo es benevolo, el Sol en Virgo es tan bueno como el buen pan." (10)

La significación moral o religiosa de los astros fue otra vertiente de gran desarrollo, y es la que vemos de manera más recurrente en La novena maravilla. 
Si Santo Tomás -en un símil que parece ser propio del Lunarejo- está representado por la constelación de Tauro (porque era llamado 'buey'), Espinosa Medrano encuentra, basándose en una alegoría astrológica de Gregorio Magno (según la cual "esse Cielo luzidamente salpicado de Astros es la Militante Iglesia" 241a), que las Hyadas, las estrellas que coronan la cabeza del toro, son los Doctores de la Iglesia, que destilan sabiduría como esos astros el rocío.

En un sermón que predica en un convento se refiere en una parte a Orfeo y su imagen celestial. Aunque la tradición emparentaba esta figura con Cristo, el Lunarejo hábilmente la relacionará con Maria, "Lyra de los Cielos" 47b. La imagen de la lira en el firmamento tiene una corona de estrellas, que el autor designará en este caso como las monjas dominicas -su auditorio- que siguen a la Virgen en su canto a Cristo. Este tipo de apelación directa al auditorio debía tener mucha eficacia en la persuasión, en este caso para que las monjas del convento siguieran rectamente el ejemplo de Maria.

La relación alegórica entre la música y las esferas es también un motivo repetido. En el barroco, dice Angus Fletcher, esta asociación entre el cosmos y la música había devenido norma convencional, conformando incluso algunos tópicos que formaban parte de la preparación humanística general (Alegoría 139). Espinosa Medrano no se sustrajo a la norma, y sus constantes alusiones musicales (cf. Cisneros) se entrelazan a veces con la "armonia Celestial" (42b), como en el caso del sermón predicado en el convento.

\section{Alegorías mitológicas}

El Lunarejo empieza una gran parte de los sermones de La novena maravilla con una alusión mitológica, y en algunos sermones llega a incorporar tres o cuatro fábulas de la gentilidad. Esto supone un deslumbrante alarde de familiaridad con este elemento importantísimo de la cultura humanística. Si bien es verdad que algunos personajes son sólo aludidos o poco profundizada su relación en el sermón, la abundancia y variedad, sin embargo, de este elemento culturalista es abrumadora. Esto confirma tanto la intención como la recepción culta de los sermones (al menos confirma el hecho de que una parte del público era permeable a ese tipo de referencias).

El uso exuda, por un lado, voluntad emulativa: Paravicino, su gran modelo, usaba de la mitología con mucha frecuencia. Comenta, al respecto, Emilio Alarcos: "Con el mismo derecho que un poeta se servía de una fábula mitológica para un auto sacramental, podía un predicador utilizarla para una alegoría o una comparación conceptuosa" 278 , y por otro, culturalista. Sin embargo, es cierto también que ese universo simbólico compartido, ese imaginario común que se concretaba en pinturas (arte efímero como emblemas, arcos triunfales, poemas de circunstancia, etc.), hacía pertinente la utilización de un sistema de referencias en el que los hechos o personajes bíblicos o de la liturgia cristiana terminen de encontrar toda su significación en la alegoría, como veremos. 
El modo más común de incorporar las alegorías mitológicas al sermón es, según lo expuesto supra, la declaración de que la Antigüedad conoció los misterios y los codificó para una adecuada protección frente a la ignorancia, los 'mintió' envolviéndolos en fábulas prodigiosas; y la interpretación logra desandar ese camino para ver la verdad detrás de lo fabulado, verdad que se expone en el discurso. Sin embargo, a veces el movimiento troca en el inverso: no se piensa a la mitología como un disfraz de verdades sino al cristianismo aprovechando y reemplazando cultos -actualizándolos- que otrora fueron del gentilismo. Por ejemplo, en el sermón de la Purificación de la Virgen señala el Lunarejo que esta fiesta fue instituida

por desterrar el abuso de la Romana Gentilidad, que este dia celebrava à la Diosa Ceres, en memoria, de quando con la tea ardiente en las manos buscava à su robada Proserpina por los sombrios bosques del Ethna. Y assi oy la solemnizavan con antorchas encendidas en las manos. Quiso la Iglesia dexar la ceremonia, y trocar el culto. Mandò, que à la Virginal Ceres Maria se le dedicasse el festivo vulgo de antorchas, y candelas con que oy la protestamos Madre pura de la luz increada. 95a

Del mismo modo sucede cuando se trata de explicar el fenómeno de la imagen mariana de la Caridad en el Templo de San Lucar -la lámpara de aceite apareció encendida cuando nadie había echado aceite-, en un sermón dedicado a la Asunción. Entonces dice Espinosa Medrano que tal prodigio no le extraña, pues "yà sucedió en Athenas" (115b), en el Templo de Minerva, y

si esso passa en honor de la Minerva, que cayò del Cielo a la tierra: De Coelo delapsae. En gloria de la Minerva, que de la tierra sube al Cielo, què novedad puede hazer essa maravilla? 116a

Asimismo, cuando se refiere al culto a la estrella de Venus, el lucero del alba, opone al "Luzero cierto" (117a), que es María, también madre del amor, pero del amor verdadero. Esta alegoría no está tomada de Berçuire, como pudiera parecer por unas palabras de nuestro autor. Tanto Natal Conti como Pérez de Moya (que copia lo del primero) hablan de varias Venus, según vimos antes. Pero aún cuando la idea de diferentes tipos de amor está presente en los mitógrafos consultados por Espinosa Medrano (a Berçuire y Natal Conti los cita con frecuencia, como dijimos. No así a Pérez de Moya, quizás porque carece del prestigio de aquéllos. No obstante, su biblioteca contenía un ejemplar de su Filosofía secreta), no encontramos la identificación entre Venus madre del amor y la Virgen Maria, "la Pura, la Virginea, la Madre de el Amor" (117). Sí aparece la relación entre la estrella que sale antes que el sol y la Virgen en un libro español de concordancias de 1620. Es muy probable que esta nueva identificación tenga que ver con la intensificación del fervor mariano. El Lunarejo agrega, en el sentido explicado más 
arriba: "Passense, pues, los pensamientos vanos del primer Luzero à practicarse modestamente en el segundo" (117a).

A la inversa, en un movimiento ácrono, la fiesta de las vestales, en que los romanos tenían encendido permanentemente el fuego para Vesta, sin permitir que se apagase, habría sido robada de las fiestas mandadas en el Levítico: "Hurtò la Gentilidad esta ceremonia de las Sagradas de el Levitico, en que mandava Dios, que perpetuamente ardiesse fuego en su Altar"120

En cambio, generalmente la relación se da al revés: como se describió más arriba, las fábulas se explicaron, en el seno del cristianismo, como cifras de la Verdad. Así, en el panegírico dedicado a la Concepción de la Virgen Espinosa Medrano abre el sermón con la fábula de Andrómeda y Perseo, y dice a continuación: "Esta solia ser fabula, y oy la venero verdad sagrada, pues en ella descubro los disseños de la pureza, en que fue concebida MARIA SANTISSIMA." $49 \mathrm{El}$ autor sostiene que Andrómeda sería la Virgen María (ambas nacieron blancas de oscuros padres), cuya madre, Eva, pecó por soberbia, por lo que el alma de María se debatía entre la culpa y la pureza: era el momento en que la bestia marina estaba por devorar a Andrómeda. La otra identificación es la del monstruo de la fábula con un animal mitad pez y mitad dragón, que promediando el sermón será el Leviatán. Por supuesto, Perseo es Cristo que mató al monstruo - la culpa- y "recavò con la prometida Divinidad la culpa original" 49.

No encontramos tampoco esta identificación entre Andrómeda y María en los mitógrafos que trabajamos. Berçuire se refiere a ella como el alma humana heredera del paraíso, cuya madre fue Eva, pero nada sobre la Virgen. Inclusive el auto de Calderón, Andrómeda y Perseo, también llega hasta considerar a Andrómeda un símbolo de la naturaleza humana salvada por Jesucristo. Es evidente que el ardor inmaculista del Lunarejo lo lleva a extender las alegorías que encuentra conformadas para consignar figuras de María y de su concepción.

En cambio, sí se refiere Berçuire a María en la fábula de Júpiter y Dánae. Ésta es encerrada por su padre en una torre para guardar su virginidad; Júpiter, enamorado por su belleza, se transforma en lluvia de oro y profanando la torre se posa en su regazo y la embaraza de Perseo. El benedictino propone que

estas cosas pueden significar a la virgen gloriosa que estuvo en la torre de la fee que por iupiter, que es ihesu xpisto por el spiritu santo fue enpreñada y por santidat fue ante ella la luvia del parayso. ${ }^{4}$ (Berçuire 118).

${ }^{4}$ El texto Morales de Ovidio de Pierre Berçuire, en la edición paleográfica que conseguimos, es de difícil lectura y transcripción. Hemos optado por normalizar las " $\mathrm{j}$ ” por "i", "u" por "v" y viceversa, y quitar los numerosos " $<>$ " que encierran, suponemos, reposiciones, pero que en nuestro trabajo no resultan imprescindibles. 
De esta misma manera -aunque Jesucristo es Perseo, no Júpiter, ya que es fecundado por Dios en el vientre de Maria- es explicada la fábula por Espinosa Medrano en el Sermón primero, à la Encarnacion, donde una vez que consigna la alegoría, citando a Berçuire, acentúa la parte que conviene al dogma inmaculista:

Esto es, que en la inefable Encarnacion, por no intervenir concurso de varon, se infundiò en sus entrañas con la limpieza, que cernida en perlas desciende la lluvia de las nubes. $35 \mathrm{~b}$

Jesucristo es, como puede esperarse, continuamente alcanzado por las alegorías. En la "Oracion Panegyrica al Augustissimo Sacramento de el Altar" (el primero del compendio) Cristo es, siguiendo a Berçuire, Acteón. Si el personaje mitológico fue convertido en ciervo y devorado por sus perros, también el hijo de Dios se convirtió en hombre y fue desconocido por los hebreos, que lo mataron (8). Pocos párrafos antes es Jacinto, muerto accidentalmente y convertido en flor, que ostenta en sus pétalos el "ay" quejumbroso, de lamento, y leído al revés, las primeras letras del nombre. Aquí dice el Lunarejo tomar la alegoría de Berçuire; sin embargo, éste consigna, en las Morales de Ovidio, como alegoría de la transformación del jacinto en flor

los martires que por ocasión del sol que es por ihesu xpisto son muertos por quanto dado que el cuerpo en la tierra muera / enpero el alma en flor de eterna gloria se muda según el salmo 238

En cambio, Espinosa Medrano dice de Jacinto que es Cristo que, yendo a buscar flores -almas, pecadores- es herido por yerro (en paronomasia con el hierro de la barra que habría herido de muerte al joven) de Adán y, derramada, su sangre se convierte en oblea rubricada con el "ay" (6b). En otro sermón, sin embargo, más de acuerdo con la idea de los mártires que propone Berçuire, Jacinto es Blas, que muerto por los vientos de la idolatría que soplaron persecuciones en la Iglesia, de sus gotas de sangre brotaron siete mártires, jacintos rojos. (134b).

En la salutación del tercer sermón de La novena maravilla, Cristo es Prometeo, quien entregó el fuego -la vida- a los hombres y cuyo corazón es perpetuamente devorado y renace sacramentalmente (19). En la Oracion Panegyrica de Nuestra Señora de la Antigua, es Hércules que en lugar de la leche de Juno mamó la divina de María y, "con el candido nectar inmortalizado" (67a) mató a la serpiente del pecado.

La lista, en fin, podría ser muy larga, pero no tiene mayor sentido proseguir un catálogo que puede leerse en el sermonario. Lo importante era dar algunos ejemplos que den cuenta del modo en que el autor trae al sermón las humanidades y usa de un método en principio ajeno a la institución. 
Junto con el obvio objetivo doctrinal inherente al sermón desde sus inicios y el de persuadere propio de la oratoria están las prerrogativas contrarreformistas para acceder a lo más profundo de la voluntad del auditorio, la apelación a los distintos niveles emotivos del público, la necesidad de calar hondo en él mediante todos los artificios posibles. Además, la exigencia de preparación por parte del Concilio de Trento lleva a la necesidad de evidenciar estudio, conocimiento y formación por parte del predicador. Aun cuando las letras humanas no tenían el peso axiomático de las divinas, eran apreciadas y muy admiradas. Si bien la preceptiva sagrada se empeñaba en conservar el lugar de humildad y 'perfil bajo' de los predicadores, en la práctica el púlpito, como vimos, pasa a ser otro lugar de enunciación apropiado para la demostración de ingenio, conocimientos y novedad. De manera correlativa, el público esperaba ese despliegue que lo enaltecía como auditorio y -aunque censurado esto también por todos los preceptistas- juzgaba y criticaba al predicador por su sermón. La necesidad de seducir al auditorio, primordial para cualquier orador, sumada a la ostentación erudita, tan común a la época y, por último, a la necesidad de la sociedad letrada virreinal de ser leída por el público culto europeo, dan como resultado una prosa abundante en recursos barrocos doctos y sensuales, en la que se recicla el mismo material mitológico milenario, se le da vueltas, se le agrega densidad semántica y se devuelve rico en imágenes y asociaciones, a la espera de un público que goce en develarlas.

\section{BIBLIOGRAFÍA}

SAN Agustín.

1792 Los libros de la Doctrina Christiana de N.G.P. S. Agustin segun la edicion de S. Mauro. 2 Tomos. Madrid: Benito Cano.

ALARCOS, Emilio.

1937 "Paravicino y Góngora" y "Los sermones de Paravicino", RFE XXIV, pp. 83-88 y 162-319.

ARAGÜÉZ ALDAZ, José.

2002 "Preceptiva, sermón barroco y contención", Criticón 84-85, pp. 8199.

BERÇUIRE, Pierre.

1992 Text and Concordance of Morales de Ovidio. A Fifteenth-Century Castilian Translation of the Ovidius Moralizatus. Madrid, Biblioteca Nacional ms. 10144. Editado por Derek C. Carr. Madison: The Hispanic Seminary of Medieval Studies.

BOCCACCIO, Giovanni.

1983 Genealogía de los dioses paganos. Madrid: Editora nacional. 
CANTÚ, César.

1858 Historia universal. Tomo VIII. Madrid: Imprenta de Gaspar y Roig,

CARR, Derek C. editores.

1997 "La transformación de las Transformaciones: el caso de los Morales de Ovidio, traducción castellana del Ovidius Moralizatus de Pierre Berçuire (Madrid, B.N. Ms. 10144, ¿ca. 1435?)”, en Daniela Boccassini (ed.), Studi filologici e letterari in memoria di Danilo Aguzzi-Barbagli. New York: Filibrary.

CISNEROS, Luis Jaime.

1984 "Sobre Espinosa Medrano: predicador, músico y poeta", Cielo Abierto X 28, pp. 3-8.

Colombí-Monguió, Alicia.

2000 "Erudición humanista en saber omnicomprensivo e identidad colonial", en Karl Kohut y Sonia Rose (eds.), La formación de la cultura virreinal. Tomo I. La etapa inicial. Frankfurt/Madrid: Vervuert/Iberoamericana, pp. 75-92.

CONTI, Natal.

2006 Mitología. Traducción, introducción, notas e índices Rosa Iglesias Montiel y Ma. Consuelo Álvarez Morán. Murcia: Universidad de Murcia.

CROSAS LÓPEZ, Francisco.

2010 De enanos y gigantes. Tradición clásica en la cultura medieval hispánica. Madrid: Universidad Carlos III.

CURTIUS, Ernst Robert.

1955 Literatura europea y Edad Media latina. Traducción de Margit Frenk Alatorre y Antonio Alatorre. México: FCE.

ESPINOSA MEDRANO, Juan de.

1695 La novena maravilla nuebamente hallada en los Panegiricos sagrados qen varias Festividades dixo el Sor. Arcediano Dor. D. Iuan de Espinosa Medrano primer Canonigo Magistral Tesorero Chantre y finalmente Arcediano de la Cathedral del Cuzco en los Reynos del Piru. Valladolid: por Joseph de Rueda.

FLETCHER, Angus.

2002 Alegoría. Teoría de un modo simbólico. Madrid: Akal.

GRACIÁN, Baltasar.

1942 Agudeza y arte de ingenio. Buenos Aires: Espasa Calpe.

GUTHRIE, W.

1992 Historia de la filosofía griega: Platón, segunda época y la Academia. Madrid: Gredos. 
HOPKINS RODRÍGUEZ, Eduardo.

2002 "La problemática del receptor en Juan Espinosa Medrano". Homenaje a Luis Jaime Cisneros. Lima: Fondo Editorial PUCP, pp. 973-1007.

MÂLE, Émile.

2001 El arte religioso del siglo XIII en Francia. Madrid: Ediciones Encuentro.

MUJICA PINILLA, Ramón.

2001 "Humanismo y escatología en el Barroco Peruano: aproximaciones a la mentalidad simbólica", en La producción simbólica en la América colonial. México: UNAM.

PANOFSKY, Erwin.

2012 Estudios sobre iconología. Prólogo de Enrique Lafuente Ferrari. Versión española de Bernardo Fernández. Madrid: Alianza.

RENAN, Ernest.

1946 Estudios de historia religiosa. Buenos Aires: Alda.

REYNOLDS, Leighton y Nigel WILSON.

1995 Copistas y filólogos. Las vías de transmisión de las literaturas griega y latina. Madrid: Gredos.

RUBIÓ Y LLUCH, Antonio.

1879 Estudio crítico-bibliográfico sobre Anacreonte y la Colección Anacreóntica, y su influencia en la literatura antigua y moderna. Tésis doctoral leída el 9 de noviembre de 1878 en la Facultad de Filosofia y Letras de la Universidad de Madrid. Barcelona: Imprenta de la viuda e hijos de J. Subirana.

SEZNEC, Jean.

1985 Los dioses de la Antigüedad en la Edad Media y el Renacimiento. Versión castellana de Juan Aranzadi. Madrid: Taurus.

VALERo MoReno, Juan Miguel.

2005 "La Expositio Virgilianae de Fulgencio: poética y hermenéutica", Revista de poética medieval 15, pp. 112-192.

WARDROPPER, Bruce.

1953 Introducción al teatro religioso del Siglo de Oro. La evolución del auto sacramental 1500-1648. Madrid: Revista de Occidente.

WEISBACH, Werner.

1948 El barroco, arte de la Contrarreforma. Buenos Aires: EspasaCalpe. 